\title{
Effects of whole-plant corn silage hybrid type on intake, digestion, ruminal fermentation, and lactation performance by dairy cows through a meta-analysis
}

\author{
L. F. Ferraretto and R. D. Shaver ${ }^{1}$ \\ Department of Dairy Science, University of Wisconsin, Madison 53706
}

\begin{abstract}
Understanding the effect of whole-plant corn silage (WPCS) hybrids in dairy cattle diets may allow for better decisions on hybrid selection by dairy producers, as well as indicate potential strategies for the seed corn industry with regard to WPCS hybrids. Therefore, the objective of this study was to perform a meta-analysis using literature data on the effects of WPCS hybrid type on intake, digestibility, rumen fermentation, and lactation performance by dairy cows. The meta-analysis was performed using a data set of 162 treatment means from 48 peer-reviewed articles published between 1995 and 2014. Hybrids were divided into 3 categories before analysis. Comparative analysis of WPCS hybrid types differing in stalk characteristics were in 4 categories: conventional, dual-purpose, isogenic, or low-normal fiber digestibility (CONS), brown midrib (BMR), hybrids with greater NDF but lower lignin (\%NDF) contents or high in vitro NDF digestibility (HFD), and leafy (LFY). Hybrid types differing in kernel characteristics were in 4 categories: conventional or yellow dent (CONG), NutriDense (ND), high oil (HO), and waxy. Genetically modified (GM) hybrids were compared with their genetically similar non-biotech counterpart (ISO). Except for lower lignin content for BMR and lower starch content for HFD than CONS and LFY, silage nutrient composition was similar among hybrids of different stalk types. A $1.1 \mathrm{~kg} / \mathrm{d}$ greater intake of DM and 1.5 and $0.05 \mathrm{~kg} / \mathrm{d}$ greater milk and protein yields, respectively, were observed for BMR compared with CONS and LFY. Likewise, DMI and milk yield were greater for HFD than CONS, but the magnitude of the difference was smaller. Total-tract NDF digestibility was greater, but starch digestibility was reduced, for BMR and HFD compared with CONS or LFY. Silage nutrient composition was similar for hybrids of varied kernel characteristics, except for lower CP and EE content for CONG than ND and HO. Feeding HO WPCS
\end{abstract}

Received October 30, 2014.

Accepted December 23, 2014.

${ }^{1}$ Corresponding author: rdshaver@wisc.edu to dairy cows decreased milk fat content and yield and protein content compared with the other kernel-type hybrids. Hybrids varying in kernel characteristics did not affect intake, milk production, or total-tract nutrient digestibilities by lactating dairy cows. Nutrient composition and lactation performance were similar between GM and ISO. Positive effects of BMR and HFD on intake and milk yield were observed for lactating dairy cows, but the reduced total-tract starch digestibility for these hybrids merits further study. Except for negative effects of $\mathrm{HO}$ on milk components, differences were minimal among corn silage hybrids differing in kernel type. Feeding GM WPCS did not affect lactation performance by dairy cows.

Key words: corn silage, hybrid, meta-analysis, dairy cow

\section{INTRODUCTION}

Whole-plant corn silage (WPCS) is the predominant forage used by the dairy industry in the United States (Johnson et al., 1999; Klopfenstein et al., 2013) with more than 2.5 million hectares of corn harvested as silage in 2013 (USDA-ERS, 2014). Shaver and Kaiser (2011) reported that forage comprises 50 to $60 \%$ of TMR DM in high-producing dairy herds with WPCS comprising 40 to $70 \%$ of the forage DM. Therefore, improvements in the nutritional quality of WPCS through hybrid selection can benefit dairy farmers through improved lactation performance or efficiency of feed utilization.

Traditionally, WPCS was produced by planting hybrids with high grain yield characteristics. Conventional or dual-purpose hybrids allow farmers the opportunity to harvest either corn grain or WPCS according to feed inventory needs. More recently, however, farmers are planting and harvesting more silage-specific hybrids with the aim of improved nutritional characteristics of WPCS to address the needs of high-producing dairy cows. Nutritional quality of WPCS can be improved through alterations in stalk or kernel characteristics. Stalk characteristics are usually modified with the aim of increasing the digestibility of fiber in WPCS. This 
has occurred primarily through reduction in the lignin fraction of NDF using brown midrib mutant lines ( Jung et al., 2012). Leafy type hybrids, which have more leaves above the ear than other hybrids, are commonly used silage-specific hybrid by farmers and have the advantage of high whole-plant DM yields (Glenn, 2013). Although the stay-green characteristic (SG) delays the dry-down of stalks, which is beneficial for grain production (Thomas and Smart, 1993), it also exists in hybrids used for WPCS production in some areas (Arriola et al., 2012a,b). Grain characteristics are altered through modifications in nutrient or starch composition. Change in nutrient composition is usually related to greater $\mathrm{CP}$ and fat contents, such as NutriDense or high-oil hybrids, at the expense of starch content. Change in starch composition is related to the selection of hybrids with starch high in amylopectin versus amylose or hybrids with more floury type endosperm (Giuberti et al., 2014).

Genetically modified (GM) corn hybrids for insect resistance or herbicide tolerance (Clark and Ipharraguerre, 2001; Faust, 2002) are becoming more important for corn production. These hybrids represented $93 \%$ of planted corn in the United States (USDS-ERS, 2014) in 2014. The use of GM corn resulted in enhanced yields and reduced exposure to environmental risks (Shi et al., 2013), and thereby provided economic benefits for farmers in the United States (Hutchison et al., 2010; Nolan and Santos, 2012). Possibly GM corn may also be of benefit to dairy farmers that grow GM corn hybrids for silage production.

Although numerous reports on feeding trials with lactating dairy cows assessing the effects of various WPCS hybrid types can be found, attempts to quantify observed responses do not exist in the literature. A quantitative review may provide information for better decision making on hybrid selection by dairy producers and their nutritionists, as well as indicate potential strategies for the seed corn industry with regards to WPCS. Therefore, the objective of this study was to perform a meta-analysis using literature data on the effects of WPCS hybrid type on intake, digestibility, rumen fermentation, and lactation performance by dairy cows.

\section{MATERIALS AND METHODS}

To create a database to be used for the meta-analysis, a literature search was conducted using CAB, Google Scholar, PubMed, and ScienceDirect. The following key words were used: corn, maize, silage, hybrids, varieties, dairy cows, and dairy cattle. References included in the respective papers were also checked. The peer-reviewed articles included in the data set were with lactating dairy cows fed TMR and compared WPCS hybrid types. To avoid confounding factors within trials, only treatment means allowing for hybrid comparisons were used. For example, Kung et al. (2008) compared conventional corn silage harvested at normal cutting height, conventional corn silage harvested at higher cutting height, and BMR corn silage harvested at normal cutting height. The conventional corn silage harvested at higher cutting height was not used. This approach was also used in the following manuscripts: Tine et al. (2001), Moreira et al. (2003), Ebling and Kung (2004), and Akins and Shaver (2014). Despite the 5 to 10 percentage units greater WPCS (DM basis) in BMR diets compared with diets containing other hybrids, the following manuscripts were kept in the data set because this is representative of a common ration formulation practice by dairy nutritionists: Bal et al. (2000; experiment 2), Oba and Allen (2000a,b), Cherney et al. (2004), and Gehman et al. (2008). Subsequently, a data set comprised of 162 treatment means from 54 feeding trials reported in 48 peer-reviewed articles published 1995 through 2014 was used for the meta-analysis (Appendix Tables A1 and A2). Comparative analysis of WPCS hybrid types differing in stalk characteristics were in 4 categories: conventional, dual-purpose, isogenic, or low-normal fiber digestibility (CONS), brown midrib (BMR), hybrids with greater NDF but lower lignin (\%NDF) contents or high in vitro NDF digestibility (HFD), and leafy (LFY). Hybrid types differing in kernel characteristics were in 4 categories: conventional or yellow dent (CONG), NutriDense (ND), high oil (HO), and waxy (WX). Genetically modified hybrids were compared with their genetically similar nonbiotech counterpart (ISO). Four trials compared a GM hybrid against 2 commercial hybrids in addition to the genetically similar non-biotech counterpart (Grant et al., 2003; Ipharraguerre et al., 2003; Phipps et al., 2005; Castillo-Lopez et al., 2014), and one trial compared CON versus GM at both early and late maturity in 2 trials (Folmer et al., 2002). Thus, the larger sample size for CON than GM hybrids (21 versus 13, respectively). Trials with factorial arrangement of treatments were divided into 2 studies to avoid confounding factors. For example, Gehman et al. (2008) compared a dualpurpose versus a BMR WPCS in diet with or without monensin. In this case, the diets containing monensin were considered an experiment and without monensin another. This approach was used in 18 manuscripts (LaCount et al., 1995; Kuehn et al., 1999; Bal et al., 2000, experiments 1 and 3; Oba and Allen, 2000a,b; Weiss and Wyatt, 2000, 2002, 2006; Clark et al., 2002; Qiu et al., 2003; Fernandez et al., 2004; Taylor and 
Table 1. Descriptive statistics for dependent variables and selected diet nutrient composition from experiments used in the meta-analysis

\begin{tabular}{|c|c|c|c|c|c|}
\hline Item & No. & Average & SD & Minimum & Maximum \\
\hline \multicolumn{6}{|c|}{ Corn silage nutrient composition } \\
\hline DM, $\%$ of as fed & 126 & 34.9 & 3.6 & 25.7 & 43.3 \\
\hline $\mathrm{CP}, \%$ of $\mathrm{DM}$ & 118 & 7.9 & 0.8 & 6.2 & 9.8 \\
\hline $\mathrm{NDF}, \%$ of DM & 126 & 41.5 & 3.7 & 32.8 & 52.8 \\
\hline $\mathrm{ADF}, \%$ of $\mathrm{DM}$ & 107 & 24.2 & 2.5 & 18.5 & 31.8 \\
\hline Lignin, \% of DM & 86 & 2.6 & 0.8 & 0.9 & 5.3 \\
\hline Starch, \% of DM & 107 & 31.2 & 5.4 & 15.9 & 45.9 \\
\hline Ash, $\%$ of DM & 68 & 4.5 & 0.9 & 2.6 & 6.7 \\
\hline \multicolumn{6}{|l|}{ TMR nutrient composition } \\
\hline $\mathrm{CP}, \%$ of $\mathrm{DM}$ & 147 & 17.2 & 1.4 & 12.7 & 20.4 \\
\hline $\mathrm{NDF}, \%$ of $\mathrm{DM}$ & 145 & 31.8 & 3.9 & 24.2 & 41.0 \\
\hline Starch, \% of DM & 86 & 27.5 & 3.8 & 19.9 & 37.6 \\
\hline \multicolumn{6}{|l|}{ Lactation performance } \\
\hline DMI, $\mathrm{kg} / \mathrm{d}$ & 150 & 24.0 & 3.1 & 13.9 & 31.5 \\
\hline Milk, kg/d & 153 & 37.1 & 5.4 & 22.3 & 49.0 \\
\hline $3.5 \% \mathrm{FCM}, \mathrm{kg} / \mathrm{d}$ & 111 & 37.6 & 5.8 & 18.7 & 50.8 \\
\hline Milk fat, \% & 150 & 3.60 & 0.33 & 2.40 & 4.30 \\
\hline Milk protein, \% & 150 & 3.11 & 0.19 & 2.71 & 3.56 \\
\hline MUN, mg/dL & 73 & 14.8 & 2.9 & 8.4 & 24.5 \\
\hline \multicolumn{6}{|l|}{ Digestibility, $\%$ of intake } \\
\hline Total-tract DM & 75 & 66.0 & 5.7 & 52.4 & 79.4 \\
\hline Total-tract OM & 69 & 66.9 & 5.3 & 54.1 & 75.8 \\
\hline Ruminal NDF & 10 & 33.9 & 9.4 & 18.2 & 48.2 \\
\hline Total-tract NDF & 81 & 43.8 & 10.0 & 24.2 & 62.5 \\
\hline Ruminal starch & 10 & 49.5 & 12.2 & 24.0 & 66.4 \\
\hline Total-tract starch & 59 & 91.8 & 5.5 & 79.7 & 99.0 \\
\hline \multicolumn{6}{|l|}{ Ruminal fermentation } \\
\hline $\mathrm{pH}$ & 63 & 6.07 & 0.36 & 5.30 & 6.97 \\
\hline Ammonia, mg/dL & 39 & 9.5 & 2.6 & 5.5 & 15.9 \\
\hline Total VFA, mM & 64 & 119.7 & 18.6 & 80.4 & 156.1 \\
\hline Acetate, $\mathrm{mol} / 100 \mathrm{~mol}$ & 64 & 58.2 & 4.4 & 47.8 & 66.1 \\
\hline Propionate, mol/100 mol & 64 & 23.7 & 4.2 & 16.9 & 35.9 \\
\hline Butyrate, $\mathrm{mol} / 100 \mathrm{~mol}$ & 64 & 12.8 & 1.3 & 9.6 & 15.6 \\
\hline
\end{tabular}

Allen, 2005a,b,c; Benefield et al., 2006; Gehman et al., 2008; Castro et al., 2010; Holt et al., 2010, 2013a,b; Ramirez et al., 2012).

The dependent variables evaluated were WPCS nutrient composition; actual-milk and 3.5\% FCM yields, milk fat, protein, and urea-nitrogen (MUN) concentrations, milk fat and protein yields, DMI, actual-milk and $3.5 \%$ FCM feed conversions, ruminal digestibilities of dietary NDF and starch, total-tract digestibilities of diet DM, OM, NDF, and starch (TTSD), and rumen $\mathrm{pH}$, ammonia-N concentration, total VFA concentration, and acetate, propionate, and butyrate molar proportions. Ruminal NDF and starch digestibility data were from experiments with ruminally and intestinally cannulated lactating dairy cows. Descriptive statistics for dependent variables included in the analysis and selected diet nutrient composition are presented in Table 1. Data were analyzed using the Mixed procedure of SAS (SAS Institute Inc., 2004); the model included the fixed effects of treatment and the random effect of trial, and treatments were weighted according to the number of experimental units reported in each article (St-Pierre, 2001). Statistical significance and trends were declared at $P \leq 0.05$ and $P>0.05$ to $P \leq 0.10$, respectively.

\section{RESULTS AND DISCUSSION}

\section{Stalk Characteristics}

Effects of WPCS hybrids with different stalk characteristics on adjusted least squares means for nutrient composition are in Table 2. Concentrations of DM, NDF, and ADF were similar $(P>0.10)$ among hybrids and averaged $33.7,43.2$ and $24.9 \%$, respectively. Ruminal in vitro NDF digestibility at 30 or $48 \mathrm{~h}$ (ivNDFD; $\%$ of NDF) was 9.4 percentage units greater $(P=$ 0.001) for BMR than the other hybrid types and related to the lower $(P=0.001)$ lignin content of BMR and corresponding decreased cross-linking of lignin to other fibrous components (Jung et al., 2012). But no differences in ivNDFD were observed among CONS, HFD, and LFY hybrids. Jung and Lauer (2011) summarized data from the University of Wisconsin silage performance trials from 1995 to 2010, and reported 8 percentage units greater ivNDFD, on average, for BMR 
compared with the trial average, but no improvements were observed for LFY over the trial average. Starch content was 3.2 percentage units lower $(P=0.05)$ for HFD than CONS and LFY. Some HFD hybrids used in the meta-analysis were selected to contain greater NDF but similar lignin content to CONS and LFY silage at expense of starch. A tendency for greater $(P=0.07)$ $\mathrm{CP}$ concentration for BMR and HFD than CONS was observed. In contrast, fat concentration was greater for CONS and LFY than BMR and HFD. However, these differences were minor (range $=0.3$ percentage units). Ash content was greater $(P=0.001)$ for BMR than CONS and may be an indication of increased mineral concentration; however, not enough data are available in the literature to evaluate this premise. This result is also important because increased ash results in decreased NFC and thereby total digestible nutrients values (NRC, 2001).

Effects of corn silage hybrids with different stalk characteristics on adjusted least squares means for lactation performance by dairy cows are in Table 3 . Consumption of DM was 1.0 and $0.7 \mathrm{~kg} / \mathrm{d}$ greater $(P=$ 0.001) for BMR and HFD, respectively, compared with CONS and LFY. Lower lignin content (Table 2) and corresponding greater ruminal and total-tract NDF digestibility (Table 4) likely explains the greater DMI for cows fed BMR (Oba and Allen, 1999b). Milk yield was $1.5 \mathrm{~kg} / \mathrm{d}$ per cow on average greater $(P=0.001)$ for BMR than CONS and LFY, and cows fed HFD had 1.0 $\mathrm{kg}$ /d greater milk yield than CONS. Greater milk yield for WPCS hybrids containing greater NDF digestibility is primarily related to the greater DMI (Tine et al., 2001). Lack of difference $(P=0.84)$ in kilogram of milk per kilogram of DMI supports this premise. Despite the $1.0 \mathrm{~kg} / \mathrm{d}$ per cow greater $(P=0.01) 3.5 \% \mathrm{FCM}$ yield for BMR than CONS, the $\mathrm{kg}$ of $3.5 \% \mathrm{FCM} / \mathrm{kg}$ of DMI tended $(P=0.07)$ to be lower for BMR than CONS and LFY. Milk fat content was lower $(P=0.01)$ for BMR than CONS and LFY, but fat yield was unaffected $(P$ $=0.30$ ) by treatment. Lower milk fat content for BMR may be related to greater intake of polyunsaturated long-chain fatty acids (PUFA; g/d) with increased consumption of DM even though fat concentration was lower for BMR WPCS than CONS and LFY. Some could argue that milk fat yield was not different among treatments, but this may be due to a combination of increased secretion of long-chain fatty acids by the mammary gland due to the greater supply caused by the greater dietary intake and the inhibition of the de novo synthesis of short- and medium-chain fatty acids in the mammary gland (Grummer, 1991; Bauman and Griinari, 2003). To our knowledge, no reports of milk fatty acids profile are available in the literature comparing BMR with non-BMR WPCS to confirm this hypothesis, and further research is warranted. Milk protein concentration was similar $(P=0.42)$ among hybrids and averaged $3.07 \%$. Milk protein yield followed the same pattern as milk yield and was $0.05 \mathrm{~kg} / \mathrm{d}$ greater for BMR than CONS and LFY and $0.04 \mathrm{~kg} / \mathrm{d}$ greater for HFD than CONS $(P=0.001)$. Greater protein yield is related to the greater flow $(\mathrm{g} / \mathrm{d})$ of microbial protein to the duodenum due to greater DM and nutrient intakes (NRC, 2001). Microbial protein synthesis was previously reported to be both greater and more efficient for cows fed diets containing BMR compared with non-BMR WPCS (Oba and Allen, 2000b; Ramirez et al., 2012). Furthermore, MUN was lower $(P=0.02)$ for BMR than CONS and LFY (14.0 vs. $15.1 \mathrm{mg} / \mathrm{dL}$, on average), suggesting greater incorporation of rumen ammonia-N (Table 4) into microbial protein.

Table 2. Effect of corn silage hybrids with different stalk characteristics on adjusted least squares means for whole-plant corn silage nutrient composition $^{1,2}$

\begin{tabular}{|c|c|c|c|c|c|c|}
\hline Item & CONS & BMR & HFD & LFY & SEM & $P$-value \\
\hline $\mathrm{CP}, \%$ of $\mathrm{DM}$ & 7.8 & 8.1 & 8.1 & 8.0 & 0.2 & 0.07 \\
\hline $\mathrm{NDF}, \%$ of $\mathrm{DM}$ & 42.8 & 43.0 & 44.7 & 42.2 & 0.9 & 0.34 \\
\hline Lignin, \% of DM & $2.9^{\mathrm{a}}$ & $2.0^{\mathrm{b}}$ & $3.0^{\mathrm{a}}$ & $2.6^{\mathrm{a}}$ & 0.2 & 0.001 \\
\hline Lignin, $\%$ of NDF & $6.7^{\mathrm{a}}$ & $4.6^{\mathrm{b}}$ & $6.3^{\mathrm{a}}$ & $6.3^{\mathrm{a}}$ & 0.4 & 0.001 \\
\hline Ruminal in vitro NDFD, ${ }^{3} \%$ of NDF & $46.7^{\mathrm{b}}$ & $58.1^{\mathrm{a}}$ & $50.9^{\mathrm{b}}$ & $48.5^{\mathrm{b}}$ & 2.5 & 0.001 \\
\hline
\end{tabular}

\footnotetext{
${ }^{\mathrm{a}, \mathrm{b}}$ Means in the same row with different superscripts differ $(P \leq 0.05)$, according to Saxton (1998).

${ }^{1} \mathrm{CONS}=$ conventional, dual-purpose, isogenic, or low to normal fiber digestibility hybrids; BMR $=$ brown-midrib hybrid; HDF $=$ high fiber digestibility hybrids; LFY = leafy hybrid.

${ }^{2}$ Number of treatment means were 45, 28, 7, and 10 for CONS, BMR, HFD, and LFY, respectively.

${ }^{3}$ Ruminal in vitro NDF digestibility after 30 or $48 \mathrm{~h}$ of incubation.
} 
Table 3. Effect of corn silage hybrids with different stalk characteristics on adjusted least squares means for lactation performance by dairy $\operatorname{cows}^{1,2}$

\begin{tabular}{|c|c|c|c|c|c|c|}
\hline Item & CONS & BMR & HFD & LFY & SEM & $P$-value \\
\hline Milk, $\mathrm{kg} / \mathrm{d}$ & $37.2^{\mathrm{c}}$ & $38.7^{\mathrm{a}}$ & $38.2^{\mathrm{ab}}$ & $37.3^{\mathrm{bc}}$ & 0.8 & 0.001 \\
\hline $3.5 \% \mathrm{FCM}, \mathrm{kg} / \mathrm{d}$ & $37.6^{\mathrm{b}}$ & $38.6^{\mathrm{a}}$ & $38.5^{\mathrm{ab}}$ & $37.8^{\mathrm{ab}}$ & 0.8 & 0.01 \\
\hline Milk fat, $\mathrm{kg} / \mathrm{d}$ & 1.34 & 1.36 & 1.37 & 1.37 & 0.03 & 0.30 \\
\hline Milk protein, \% & 3.06 & 3.07 & 3.09 & 3.06 & 0.03 & 0.42 \\
\hline Milk protein, $\mathrm{kg} / \mathrm{d}$ & $1.13^{\mathrm{c}}$ & $1.18^{\mathrm{a}}$ & $1.17^{\mathrm{ab}}$ & $1.13^{\mathrm{bc}}$ & 0.02 & 0.001 \\
\hline $\mathrm{kg}$ of $3.5 \% \mathrm{FCM} / \mathrm{kg}$ of DMI & 1.58 & 1.55 & 1.57 & 1.60 & 0.03 & 0.07 \\
\hline
\end{tabular}

${ }^{a-c}$ Means in the same row with different superscripts differ $(P \leq 0.05)$, according to Saxton (1998).

${ }^{1} \mathrm{CONS}=$ conventional, dual-purpose, isogenic, or low to normal fiber digestibility hybrids; BMR = brown-midrib hybrid; HDF $=$ high fiber digestibility hybrids; LFY = leafy hybrid.

${ }^{2}$ Number of treatment means were 53, 39, 9, and 12 for CONS, BMR, HFD, and LFY, respectively.

Effects of corn silage hybrids with different stalk characteristics on adjusted least squares means for ruminal and total-tract digestibility of dietary nutrients and ruminal fermentation patterns are in Table 4. Comparison of ruminal NDF and starch digestibility was only between BMR and CONS due to lack of available data for HFD and LFY. The ruminal digestibility of dietary NDF was numerically greater $(P=0.16)$ for BMR than LFY (40.8 vs. $37.0 \%$ ), whereas a 6.6 percentage unit greater ruminal digestibility of dietary starch was observed $(P=0.01)$ for CONS compared with BMR. Total-tract nutrient digestibility analysis was performed using the 4 hybrid types. Total-tract digestibilities of diet DM and $\mathrm{OM}$ were similar $(P>$ 0.10 ) among hybrids and averaged 66.1 and $67.1 \%$, respectively. Greater NDFD was observed $(P=0.001)$ for BMR and HFD compared with CONS and LFY (46.0 vs. $42.0 \%$, on average). This is related to lower lignin content in BMR and similar lignin but greater NDF content in HFD (Table 2). The cross-linking of lignin to other fibrous components limits NDF digestibility by rumen microorganisms (Jung et al., 2012). The TTSD was greatest $(P=0.01)$ for LFY, followed by CONS, and lowest for BMR and HFD. Greatest TTSD for LFY is related to its lower vitreousness compared with dual-purpose and BMR hybrids (Glenn, 2013). Greater

Table 4. Effect of corn silage hybrids with different stalk characteristics on adjusted least squares means for ruminal and total-tract digestibility of dietary nutrients, and ruminal fermentation patterns ${ }^{1}$

\begin{tabular}{|c|c|c|c|c|c|c|}
\hline Item & CONS & BMR & HFD & LFY & SEM & $P$-value \\
\hline \multicolumn{7}{|c|}{ Ruminal digestibility, ${ }^{2} \%$ of intake } \\
\hline NDF & 37.0 & 40.8 & $\mathrm{NA}^{5}$ & NA & 4.5 & 0.16 \\
\hline \multicolumn{7}{|c|}{ Total-tract digestibility, ${ }^{3} \%$ of intake } \\
\hline DM & 65.9 & 66.0 & 66.6 & 65.8 & 1.1 & 0.89 \\
\hline $\mathrm{OM}$ & 66.8 & 67.1 & 67.2 & 67.2 & 1.0 & 0.79 \\
\hline $\mathrm{NDF}$ & $42.3^{\mathrm{b}}$ & $44.8^{\mathrm{a}}$ & $47.1^{\mathrm{a}}$ & $41.7^{\mathrm{b}}$ & 1.7 & 0.001 \\
\hline $\mathrm{pH}$ & 6.12 & 6.08 & 6.11 & NA & 0.07 & 0.19 \\
\hline Ammonia, mg/dL & 10.4 & 9.8 & 10.9 & NA & 0.9 & 0.12 \\
\hline Total VFA, mM & 117.2 & 120.0 & 118.9 & NA & 3.5 & 0.21 \\
\hline Acetate, $\mathrm{mol} / 100 \mathrm{~mol}$ & 58.6 & 58.3 & 58.8 & NA & 0.8 & 0.64 \\
\hline Propionate, mol/100 mol & 24.2 & 24.2 & 23.6 & NA & 0.8 & 0.50 \\
\hline Butyrate, mol/100 mol & 12.3 & 12.7 & 13.8 & NA & 0.5 & 0.08 \\
\hline $\mathrm{A}: \mathrm{P}$ & 2.59 & 2.53 & 2.64 & NA & 0.11 & 0.63 \\
\hline
\end{tabular}

${ }^{\mathrm{a}-\mathrm{c}}$ Means in the same row with different superscripts differ $(P \leq 0.05)$, according to Saxton (1998).

${ }^{1} \mathrm{CONS}=$ conventional, dual-purpose, isogenic, or low to normal fiber digestibility hybrids; BMR $=$ brown-midrib hybrid; HDF $=$ high fiber digestibility hybrids; LFY = leafy hybrid.

${ }^{2}$ Number of treatment means were 7 for both CONS and BMR.

${ }^{3}$ Number of treatment means were 38, 24, 8, and 7 for CONS, BMR, HFD, and LFY, respectively.

${ }^{4}$ Number of treatment means were 33,25 , and 9 for CONS, BMR, and HFD, respectively.

${ }^{5}$ Data not available. 
vitreousness for BMR compared with other hybrids was observed by Fish (2010). Furthermore, greater DMI for BMR and HFD may reduce starch digestibility through increased passage rate of starch through gastrointestinal tract of dairy cows (Firkins et al., 2001; Ferraretto et al., 2013).

Ruminal fermentation patterns analysis were performed without data for LFY. Rumen $\mathrm{pH}$ and total VFA concentration were unaffected $(P>0.10)$ by hybrid type and averaged 6.10 and $118.7 \mathrm{~m} M$. Likewise, molar proportions of acetate and propionate did not differ $(P$ $>0.10)$, resulting in a similar $(P=0.63)$ acetate to propionate ratio among hybrids. Butyrate tended $(P$ $=0.08$ ) to be greater for HFD than BMR and CONS. Rumen ammonia-N concentration approached a trend $(P=0.12)$ to be lower for BMR compared with other hybrids. These data support the premise that greater ruminal ammonia- $\mathrm{N}$ was incorporated into microbial protein and resulting in subsequent greater milk protein yield and lower MUN concentration (Table 3).

Other hybrids may be of interest but do not have enough literature available to incorporate into the present meta-analysis data set. All the studies evaluating BMR hybrids compiled in the present meta-analysis were with the $b m 3$ gene mutation which has the lowest lignin concentration and greatest cell wall digestibility of all BMR mutants (Ostrander et al., 1999; Marita et al., 2003). Research evaluating other BMR gene mutations is unavailable in the literature and further research is required to assess their use in dairy cattle diets. A recent study by Jung et al. (2011) evaluated the effects of feeding a seedling leaf ferulate ester mutant (SFE) WPCS hybrid on lactation performance and total-tract nutrient digestibility of dairy cows. Hybrids with SFE characteristic have reduced ferulate ether cross-linking of lignin to arabinoxylans and thereby possible greater digestibility of cell wall polysaccharides. Feeding SFE WPCS resulted in $1.6 \mathrm{~kg} / \mathrm{d}$ greater DMI and hence 1.6 and $1.8 \mathrm{~kg} / \mathrm{d}$ greater milk and $3.5 \%$ FCM yield compared with its isogenic counterpart. These responses are similar to those observed when comparing BMR with its isogenic counterpart in the same study. In addition, SFE WPCS increased total-tract DM, starch, and cell wall polysaccharide digestibilities. To our knowledge, this is the sole experiment evaluating SFE WPCS for dairy cows, and further research is warranted.

Hybrids containing high-SG characteristic have generated concern among dairy farmers in some areas (Arriola et al., 2012a,b). Compared with conventional hybrids, corn plants with high-SG characteristic have delayed leaf senescence and thus the stover remains green for a longer period while kernels dry down. This characteristic may cause problems for WPCS harvest. If harvesting WPCS based on DM content, farmers may harvest WPCS with proper whole-plant DM content but with mature kernels, which results in lower starch digestibility and lactation performance by dairy cows (Ferraretto and Shaver, 2012). Arriola et al. (2012b) evaluated the effect of feeding low- and high-SG characteristic WPCS at 2 maturities to lactating dairy cows. Overall, despite the reduced intake of $\mathrm{CP}$, starch, and NDF for high SG WPCS, effects on lactation performance were minimal. Although starch digestibility was not affected, high-SG WPCS had lower NDFD and ruminal total VFA concentration, and higher ruminal ammonia- $\mathrm{N}$ concentration. This was the only trial available in the literature that met all the criteria of the present meta-analysis and thus could not be included in the study data set. Also, harvesting a high-SG hybrid using milk line as indicator of maturity (Ganoe and Roth, 1992) may result in WPCS with a low DM content thereby resulting in leaching and poor silage fermentation (Xiccato et al., 1994). A laboratory silo study was conducted by Arriola et al. (2012a) comparing the high- versus average-SG characteristic for 2 hybrids harvested at 3 maturities. Ranking of the SG characteristic did not affect silage fermentation.

\section{Kernel Characteristics}

Effects of WPCS hybrids with different kernel characteristics on adjusted least squares means for nutrient composition are in Table 5. Dry matter, starch, and ash content were unaffected $(P>0.10)$ by hybrid type and averaged 35.8, 31.8, and 4.2\%, respectively. Greater $\mathrm{CP}$ concentration $(P=0.01)$ was observed for $\mathrm{ND}$ and HO than CONG. Likewise, HO had greater $(P=0.01)$ ether extract concentration than CONG. No papers reported measurement of ether extracts for ND WPCS, even though greater ether extract is a characteristic of ND (Akay and Jackson, 2001). Fiber fractions did not differ $(P>0.10)$ among hybrids, with NDF, ADF, and lignin concentrations averaging 40.7, 23.5, and $2.9 \%$, respectively.

Effects of WPCS hybrids with different kernel characteristics on adjusted least squares means for lactation performance by dairy cows are in Table 6. Milk yield and DMI were similar $(P>0.10)$ among hybrids and averaged 36.8 and $23.9 \mathrm{~kg} / \mathrm{d}$, respectively. Likewise, feed efficiency $(\mathrm{kg}$ of milk $/ \mathrm{kg}$ of DMI) did not differ $(P$ $=0.46)$. The $3.5 \%$ FCM yield tended $(P=0.10)$ to be 1.0 and $1.3 \mathrm{~kg} / \mathrm{d}$ greater for ND and WX, respectively, compared with CONG. These data suggest that ND and WX provide greater energy utilization compared with CONG, even though FCM feed efficiency was similar $(P=0.44)$ among hybrids. Further research is 
Table 5. Effect of corn silage hybrids with different kernel characteristics on adjusted least squares means for whole-plant corn silage nutrient composition $^{1,2}$

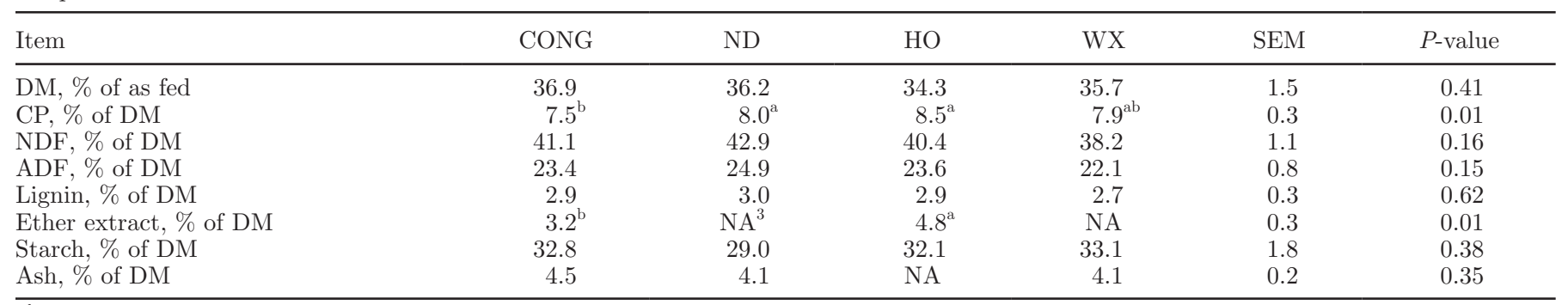

$\overline{\mathrm{a}, \mathrm{b}}$ Means in the same row with different superscripts differ $(P \leq 0.05)$, according to Saxton (1998).

${ }^{1} \mathrm{CONG}=$ conventional or yellow dent hybrids; $\mathrm{ND}=$ NutriDense hybrid; $\mathrm{HO}=$ high-oil hybrid; $\mathrm{WX}=$ waxy hybrid.

${ }^{2}$ Number of treatment means were 8, 3, 4, and 2 for CON, ND, HO, and WX, respectively.

${ }^{3}$ Data not available.

warranted to evaluate this premise. Milk fat content and yield were $0.38 \%$ and $0.10 \mathrm{~kg} / \mathrm{d}$ lower $(P<0.05)$ for HO compared with other hybrids. Dietary PUFA, such as linoleic acid in corn, influence the ruminal load of biohydrogenated conjugated fatty acids that can cause milk fat depression through inhibition of the de novo synthesis of short- and medium-chain fatty acids (Grummer, 1991; Bauman and Griinari, 2003). Although the uptake of long-chain fatty acids is also increased by the mammary gland with greater dietary supply of PUFA (Grummer, 1991), it cannot compensate for the negative effects of corn oil in the secretion of short- and medium-chain fatty acids, thereby resulting in milk fat depression (He and Armentano, 2011). Milk protein content was lower $(P=0.01)$ for HO than other hybrids, but not yield $(P=0.13)$. Concentration on MUN was similar $(P=0.25)$ between CONG and $\mathrm{ND}$, but insufficient data were available to evaluate $\mathrm{HO}$ and WX. Long-chain fatty acids may inhibit growth of ruminal bacteria (Maczulak et al., 1981), decreasing microbial protein synthesis and thereby milk protein (NRC, 2001). However, measurements of microbial protein synthesis, rumen ammonia- $\mathrm{N}$, and MUN are unavailable when evaluating the use of $\mathrm{HO}$ for dairy cows and further research is warranted to evaluate this premise.

Effects of corn silage hybrids with different kernel characteristics on adjusted least squares means for total-tract digestibility of dietary nutrients and ruminal fermentation patterns are in Table 7. Total-tract DM and $\mathrm{OM}$ digestibilities were unaffected by hybrid type and averaged 66.4 and $66.7 \%$, respectively. Despite the similarity $(P>0.10)$ in NDFD and TTSD among hybrid types, WX had the lowest NDFD and numerically higher TTSD than CONG and ND. Ruminal fermentation pattern was compared only among CONG, $\mathrm{ND}$, and WX. Rumen $\mathrm{pH}$, ammonia- $\mathrm{N}$ concentration, and total VFA concentration did not differ $(P>0.10)$ among treatments and averaged $6.07,12.9 \mathrm{mg} / \mathrm{dL}$, and $122.5 \mathrm{mM}$, respectively. Acetate molar percentage tended to be greater $(P=0.07)$ for CONG and ND compared with WX, but propionate and butyrate molar proportions were similar $(P>0.10)$. Despite the lower acetate molar percentage, acetate to propionate ratio

Table 6. Effect of corn silage hybrids with different kernel characteristics on adjusted least squares means for lactation performance by dairy cows $^{1,2}$

\begin{tabular}{|c|c|c|c|c|c|c|}
\hline Item & $\mathrm{CONG}$ & $\mathrm{ND}$ & $\mathrm{HO}$ & WX & SEM & $P$-value \\
\hline DMI, kg/d & 23.6 & 23.9 & 24.0 & 24.1 & 1.1 & 0.29 \\
\hline Milk, kg/d & 36.1 & 36.8 & 37.7 & 36.6 & 1.9 & 0.15 \\
\hline $3.5 \% \mathrm{FCM}, \mathrm{kg} / \mathrm{d}$ & 36.0 & 37.0 & 35.9 & 37.3 & 2.1 & 0.10 \\
\hline Milk fat, $\%$ & $3.51^{\mathrm{a}}$ & $3.53^{\mathrm{a}}$ & $3.18^{\mathrm{b}}$ & $3.64^{\mathrm{a}}$ & 0.11 & 0.04 \\
\hline Milk fat, $\mathrm{kg} / \mathrm{d}$ & $1.26^{\mathrm{a}}$ & $1.30^{\mathrm{a}}$ & $1.20^{\mathrm{b}}$ & $1.33^{\mathrm{a}}$ & 0.08 & 0.05 \\
\hline Milk protein, $\%$ & $3.15^{\mathrm{a}}$ & $3.15^{\mathrm{a}}$ & $3.03^{\mathrm{b}}$ & $3.21^{\mathrm{a}}$ & 0.05 & 0.01 \\
\hline Milk protein, $\mathrm{kg} / \mathrm{d}$ & 1.12 & 1.15 & 1.11 & 1.16 & 0.06 & 0.13 \\
\hline MUN, mg/dL & 12.7 & 12.3 & $\mathrm{NA}^{3}$ & NA & 0.9 & 0.25 \\
\hline $\mathrm{kg}$ of milk/kg of DMI & 1.54 & 1.54 & 1.58 & 1.52 & 0.06 & 0.46 \\
\hline $\mathrm{kg}$ of $3.5 \% \mathrm{FCM} / \mathrm{kg}$ of DMI & 1.52 & 1.54 & 1.50 & 1.55 & 0.06 & 0.44 \\
\hline
\end{tabular}

$\overline{\mathrm{a}, \mathrm{b}}$ Means in the same row with different superscripts differ $(P \leq 0.05)$, according to Saxton (1998).

${ }^{1} \mathrm{CONG}=$ conventional or yellow dent hybrids; ND = NutriDense hybrid; HO = high oil hybrid; WX $=$ waxy hybrid.

${ }^{2}$ Number of treatment means were $10,4,5$, and 2 for CON, ND, HO, and WX, respectively.

${ }^{3}$ Data not available. 
Table 7. Effect of corn silage hybrids with different kernel characteristics on adjusted least squares means for total-tract digestibility of dietary nutrients and ruminal fermentation patterns ${ }^{1}$

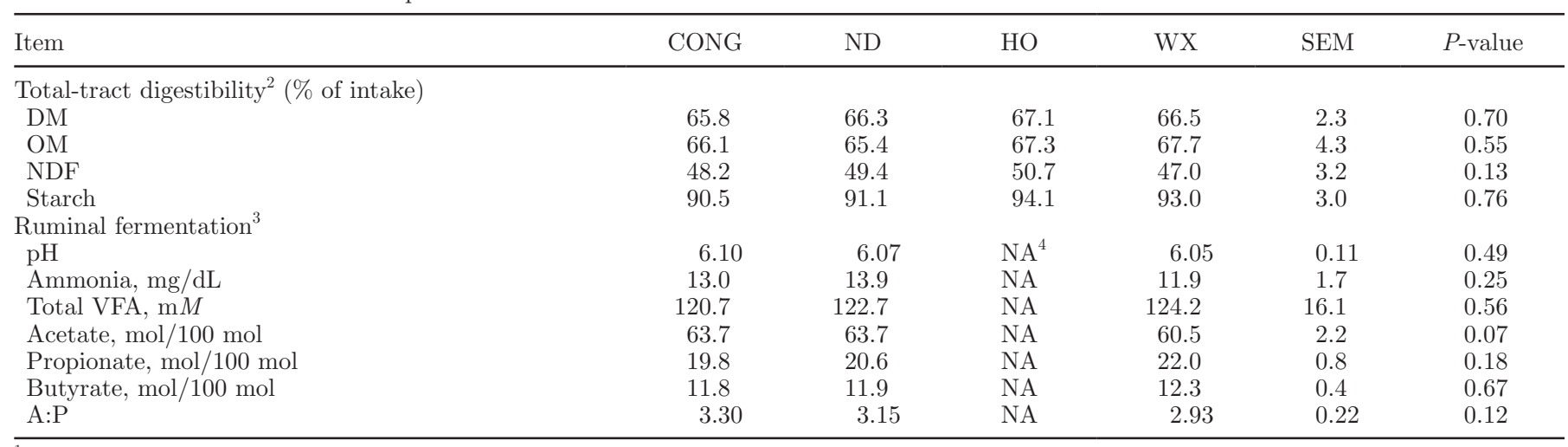

${ }^{1} \mathrm{CONG}=$ conventional or yellow dent hybrids; ND = NutriDense hybrid; HO = high oil hybrid; WX = waxy hybrid.

${ }^{2}$ Number of treatment means were $6,3,2$, and 2 for CON, ND, HO, and WX, respectively.

${ }^{3}$ Number of treatment means were 3,3 , and 1 for CON, ND, and WX, respectively.

${ }^{4}$ Data not available.

only approached a trend to be lower $(P=0.12)$ for WX compared with CONG and ND. Numerical differences in measurements of TTSD, NDFD, and ruminal fermentation patterns suggest that WX WPCS may enhance ruminal starch digestibility but this information is unavailable in the literature and further research is warranted with regard to this premise. Lack of difference may be related to the limited data set available in the literature for WPCS hybrid types of varied kernel characteristics and thereby lack of statistical power. Thus, results must be interpreted carefully and more research is warranted to better understand the use of these hybrids in dairy cattle diets.

Alteration of kernel vitreousness, ratio of floury to vitreous endosperm, is another grain characteristic of interest for selection programs of WPCS. Kernel vitreousness is negative related to ruminal in situ starch digestibility in unfermented WPCS kernels (Correa et al., 2002; Ngonyamo-Majee et al., 2009). Although reports of greater ruminal and total-tract starch digestibility when cows were fed dry ground corn containing low vitreousness are available (Taylor and Allen, 2005c; Lopes et al., 2009), comparisons of WPCS hybrids differing in vitreousness are scarce in the literature. To our knowledge, 2 peer-reviewed articles are available. Johnson et al. (2002a,b) evaluated 2 hybrids, with low and high vitreousness, at varied maturities and processing settings. These authors observed a negative relationship between kernel vitreousness and TTSD, although this relationship was greater in unprocessed compared with processed WPCS. Interestingly, however, lower floury endosperm was observed for the low vitreousness hybrid. Possible causes for this phenomenon includes potential pollen drifts (Thomison, 2002) and effects of nitrogen fertilization on prolamin content (Tsai et al.,
1978; Masoero et al., 2011). The other experiment (Correa et al., 2003) compared a low vitreousness hybrid harvested at black stage with a more vitreous hybrid harvest at $1 / 2$ milk line and observed similar starch digestibility. These data suggest that hybrids containing greater floury endosperm may attenuate the negative effects of maturity on starch digestibility (Ferraretto and Shaver, 2012). Further feeding trials evaluating WPCS hybrids of varied vitreousness are warranted to elucidate the role of vitreousness in WPCS hybrids selection programs.

\section{GM Characteristics}

Effects of GM WPCS hybrids on adjusted least squares means for nutrient composition are in Table 8. Contents of DM and $\mathrm{CP}$ were similar $(P>0.10)$ between ISO and GM and averaged 37.1 and 8.0\%, respectively. Although lignin concentration was unaffected $(P=0.73)$ by hybrid type, NDF and ADF tended $(P<0.10)$ to be 1.2 percentage units lower for ISO than GM. Starch content was $(P=0.02) 1.4$ percentage units greater for ISO than GM. Effects of GM WPCS on adjusted least squares means for lactation performance by dairy cows are provided in Table 9. No differences $(P>0.10)$ were found in DMI $(24.3$ $\mathrm{kg} / \mathrm{d}$ on average), milk yield (34.9 $\mathrm{kg} / \mathrm{d}$ on average), or milk composition for cows fed GM compared with ISO WPCS. These data suggest that dairy producers and nutritionists should not be concerned about feeding WPCS produced from GM corn when the traits make agronomic and economic sense to the grower.

Commercial transgenic corn hybrids specific for improving the nutritional quality and feeding value of WPCS for dairy cattle are not available. This is 
Table 8. Effect of genetically modified corn silage on adjusted least squares means for whole-plant corn silage nutrient composition ${ }^{1,2}$

\begin{tabular}{lrrcc}
\hline Item & ISO & GM & SEM & $P$-value \\
\hline DM, \% of as fed & 36.7 & 37.5 & 0.9 & 0.27 \\
CP, \% of DM & 8.0 & 8.0 & 0.2 & 0.88 \\
NDF, \% of DM & 39.2 & 40.4 & 0.7 & 0.10 \\
ADF, \% of DM & 23.2 & 24.4 & 0.8 & 0.06 \\
Lignin, \% of DM & 2.6 & 2.7 & 0.4 & 0.73 \\
Starch, \% of DM & 34.5 & 33.1 & 1.8 & 0.02 \\
Ash, \% of DM & 4.8 & 4.8 & 0.2 & 0.79 \\
\hline
\end{tabular}

${ }^{1} \mathrm{ISO}=$ isogenic hybrid; GM = genetically modified hybrid.

${ }^{2}$ Number of treatment means were 21 and 13 for ISO and GM, respectively.

unfortunate because progress for improving ivNDFD through conventional corn breeding techniques has been minimal over the last 100 yr. Lauer et al. (2001) compared 36 cultivars used by farmers in the northern Corn Belt from before 1930 through 1998 and reported that ivNDFD have not changed over time. This is in agreement with a recent summary of the University of Wisconsin silage performance trial results from 1995 through 2010 (Jung and Lauer, 2011). Despite the consistent response of greater ivNDFD by BMR hybrids over the years (Table 2; Jung and Lauer, 2011) and thereby greater milk per ton estimates (Lauer et al., 2009), whole-plant DM yield per acre and starch content limited their milk per acre potential (Lauer et al., 2009). Recently, Jung et al. (2011) reported improved lactation performance with SFE hybrids and suggested that combining BMR and SFE mutations in the same corn line may allow for greater improvements in animal performance because the genes and modes of action (ferulate cross-linking vs. lignin content) involved are different. Use of transgenic technology could hasten the inclusion of this and other nutritional traits in corn for silage production.

Furthermore, the use of transgenic technology could be used to alter kernel endosperm properties to improve starch digestion (Lopes et al., 2009; Lebaka et al., 2013) without the risk of potential pollen drifts (Thomison, 2002) and effects of nitrogen fertilization on prolamin content (Tsai et al., 1978; Masoero et al., 2011). Other areas with potential for improving the nutritional quality and feeding value of corn grain and silage for dairy cows with transgenics could include increased oleic with reduced linoleic acids to minimize milk fat depression with high corn silage diets (He et al., 2012), and increased protein and lysine contents to reduce supplemental needs to meet cow requirements (NRC, 2001). Further research with transgenic technology enhancing nutritional aspects of WPCS appears warranted.

\section{CONCLUSIONS}

Hybrids selected for greater fiber digestibility, such as BMR and HFD, enhanced yields of milk and protein through increased DMI. These findings highlight the importance of fiber digestibility in hybrid selection programs for silage production and reinforce its use in the formulation of diets for high-producing dairy cows. However, feed efficiency was not improved and starch digestibility was reduced when feeding these hybrids. Future incorporation of low vitreousness characteristics in the selection programs for BMR and HFD hybrids may be advantageous. Lower milk fat content when cows were fed BMR merits further evaluation. Feeding HO hybrids to lactating dairy cows depressed milk fat content and yield and protein content. Otherwise, lactation performance was minimally affected by hybrids

Table 9. Effect of genetically modified corn silage on adjusted least squares means for lactation performance by dairy cows ${ }^{1,2}$

\begin{tabular}{lcccc}
\hline Item & ISO & GM & SEM & $P$-value \\
\hline DMI, kg/d & 24.4 & 24.3 & 0.7 & 0.55 \\
Milk, kg/d & 35.0 & 34.8 & 1.3 & 0.50 \\
$3.5 \% \mathrm{FCM}, \mathrm{kg} / \mathrm{d}$ & 35.6 & 35.3 & 1.2 & 0.38 \\
Milk fat, \% & 3.62 & 3.61 & 0.06 & 0.67 \\
Milk fat, kg/d & 1.26 & 1.25 & 0.04 & 0.38 \\
Milk protein, \% & 3.19 & 3.19 & 0.05 & 0.58 \\
Milk protein, kg/d & 1.11 & 1.11 & 0.03 & 0.64 \\
MUN, mg/dL & 17.1 & 17.1 & 1.3 & 0.98 \\
\hline
\end{tabular}

${ }^{1} \mathrm{ISO}=$ isogenic hybrid; GM = genetically modified hybrid.

${ }^{2}$ Number of treatment means were 21 and 13 for ISO and GM, respectively. 
of varied kernel types. Literature evaluating WPCS hybrids of varied kernel characteristics is scarce, particularly for vitreousness, and more research is warranted to better understand the potential effect of their inclusion in dairy cattle diets. Nutrient composition of WPCS and lactation performance were unaffected by GM corn hybrids. These data suggest that GM hybrids can be used by dairy farmers when showing agronomic and economic advantages.

\section{REFERENCES}

Akay, V., and J. A. Jackson Jr.. 2001. Effects of NutriDense and waxy corn hybrids on the rumen fermentation, digestibility and lactational performance of dairy cows. J. Dairy Sci. 84:1698-1706.

Akins, M. S., and R. D. Shaver. 2014. Influence of corn silage hybrid type on lactation performance by Holstein dairy cows. J. Dairy Sci. In press.

Arriola, K. G., S. C. Kim, C. M. Huisden, and A. T. Adesogan. 2012a. Stay-green ranking maturity of corn hybrids: 1. Effects on dry matter yield, nutritional value, fermentation characteristics, and aerobic stability of silage hybrids in Florida. J. Dairy Sci. 95:964974

Arriola, K. G., S. C. Kim, C. R. Staples, and A. T. Adesogan. 2012b. Stay-green ranking maturity of corn hybrids: 2. Effects on the performance of lactating dairy cows. J. Dairy Sci. 95:975-985.

Bal, M. A., R. D. Shaver, H. Al-Jobeile, J. G. Coors, and J. G. Lauer. 2000. Corn silage hybrid effects on intake, digestion, and milk production by dairy cows. J. Dairy Sci. 83:2849-2858.

Ballard, C. S., E. D. Thomas, E. S. Tsang, P. Mandebvu, C. J. Sniffen, M. I. Endres, and M. P. Carter. 2001. Effect of corn silage hybrid on dry matter yield, nutrient composition, in vitro digestion, intake by dairy heifers, and milk production by dairy cows. J. Dairy Sci. 84:442-452.

Barlow, J. S., J. K. Bernard, and N. A. Mullis. 2012. Production response to corn silage produced from normal, brown midrib, or waxy corn hybrids. J. Dairy Sci. 95:4550-4555.

Barrière, Y., G. Dias Gonçalves, J. C. Emile, and B. Lefevre. 2004. Higher intake of DK265 corn silage by dairy cattle. J. Dairy Sci. 87:1439-1445.

Barrière, Y., R. Verite, P. Brunschwig, F. Surault, and J. C. Emile. 2001. Feeding value of silage maize estimated with sheep and dairy cows is not altered by genetic incorporation of Bt176 resistance to Ostrinia nubilalis. J. Dairy Sci. 84:1863-1871.

Bauman, D. E., and J. M. Griinari. 2003. Nutritional regulation of milk fat synthesis. Annu. Rev. Nutr. 23:203-227.

Benefield, B. C., M. Lineiro, I. R. Ipharraguerre, and J. H. Clark. 2006. NutriDense corn grain and corn silage for dairy cows. J. Dairy Sci. J. Dairy Sci. 89:1571-1579.

Brouk, M. J., B. Cvetkovic, D. W. Rice, B. L. Smith, M. A. Hinds, F. N. Owens, C. Iiams, and T. E. Sauber. 2011. Performance of lactating dairy cows fed corn as whole plants silage and grain produced from genetically modified corn containing event DAS59122-7 compared to a nontransgenic, near-isogenic control. J. Dairy Sci. 94:1961-1966.

Calsamiglia, S., B. Hernandez, G. F. Hartnell, and R. Phipps. 2007. Effects of corn silage derived from a genetically modified variety containing two transgenes on feed intake, milk production, and composition, and the absence of detectable transgenic deoxyribonucleic acid in milk in Holstein dairy cows. J. Dairy Sci. 90:4718-4723.

Castillo-Lopez, E., K. J. Clark, H. A. Paz, H. A. Ramirez Ramirez, T. H. Klusmeyer, G. F. Hartnell, and P. J. Kononoff. 2014. Performance of dairy cows fed silage and grain produced from secondgeneration insect-protected (Bacillus thuringiensis) corn (MON 89034), compared with parental line corn or reference corn. J. Dairy Sci. 97:3832-3837.
Castro, J. J., J. K. Bernard, N. A. Mullis, and R. B. Eggleston. 2010. Brown midrib corn silage and Tifton 85 bermudagrass in rations for early-lactation cows. J. Dairy Sci. 93:2143-2152.

Cherney, D. J. R., J. H. Cherney, L. E. Chase, and W. J. Cox. 2004. Milk production in high producing dairy cows as influenced by corn silage quality. Prof. Anim. Sci. 20:302-311.

Clark, J. H., and I. R. Ipharraguerre. 2001. Livestock performance: Feeding biotech crops. J. Dairy Sci. 84(E. Suppl.):E9-E18.

Clark, P. W., S. Kelm, and M. I. Endres. 2002. Effect of feeding a corn hybrid selected for leafiness as silage or grain to lactating dairy cattle. J. Dairy Sci. 85:607-612.

Correa, C. E. S., M. N. Pereira, S. M. Oliveira, and M. H. Ramos. 2003. Performance of Holstein cows fed sugarcane or corn silages of different grain textures. Sci. Agric. 60:621-629.

Correa, C. E. S., R. D. Shaver, M. N. Pereira, J. G. Lauer, and K. Kohn. 2002. Relationship between corn vitreousness and ruminal in situ starch degradability. J. Dairy Sci. 85:3008-3012.

Dhiman, T. R., G. R. Anand, L. D. Satter, and M. W. Pariza. 1999 Conjugated linoleic acid content of milk from cows fed different diets. J. Dairy Sci. 82:2146-2156.

Donkin, S. S., J. C. Velez, A. K. Totten, E. P. Stanisiewski, and G. F. Hartnell. 2003. Effects of feeding silage and grain from glyphosate-tolerant or insect-protected corn hybrids on feed intake, ruminal digestion, and milk production in dairy cattle. J. Dairy Sci. 86:1780-1788.

Ebling, T. L., and L. Kung Jr.. 2004. A comparison of processed conventional corn silage to unprocessed and processed brown midrib corn silage on intake, digestion, and milk production by dairy cows. J. Dairy Sci. 87:2519-2526.

Faust, M., B. Smith, D. Rice, F. Owens, M. Hinds, G. Dana, and P. Hunst. 2007. Performance of lactating dairy cows fed silage and grain from a maize hybrid with the cry $1 \mathrm{~F}$ trait versus its nonbiotech counterpart. J. Dairy Sci. 90:5706-5713.

Faust, M. A. 2002. New feeds from genetically modified plants: The US approach to safety for animals and the food chain. Livest. Prod. Sci. 74:239-254.

Fernandez, I., C. Martin, M. Champion, and B. Michalet-Doreau. 2004. Effect of corn hybrid and chop length of whole-plant corn silage on digestion and intake by dairy cows. J. Dairy Sci. 87:1298-1309.

Ferraretto, L. F., P. M. Crump, and R. D. Shaver. 2013. Effect of cereal grain type and corn grain harvesting and processing methods on intake, digestion and milk production by dairy cows through a meta-analysis. J. Dairy Sci. 96:533-550.

Ferraretto, L. F., A. C. Fonseca, C. J. Sniffen, A. Formigoni, and R. D. Shaver. 2015. Effect of corn silage hybrids differing in starch and NDF digestibility on lactation performance and total tract nutrient digestibility by dairy cows. J. Dairy Sci. 98:395-405.

Ferraretto, L. F., and R. D. Shaver. 2012. Meta-analysis: Impact of corn silage harvest practices on intake, digestion and milk production by dairy cows. Prof. Anim. Sci. 28:141-149.

Firkins, J. L., M. L. Eastridge, N. R. St-Pierre, and S. M. Noftsger. 2001. Effects of grain variability and processing on starch utilization by lactating dairy cattle. J. Anim. Sci. 79(E. Suppl.):E218E238.

Fish, C. M. 2010. The effect of fermentation on forage quality ranking of corn hybrids. MS Thesis. University of Wisconsin, Madison.

Folmer, J. D., R. J. Grant, C. T. Milton, and J. Beck. 2002. Utilization of Bt maize residues by grazing beef steers and Bt maize silage and grain by growing beef cattle and lactating dairy cows. J. Anim. Sci. 80:1352-1361.

Ganoe, K. H., and G. W. Roth. 1992. Kernel milkline as a harvest indicator for corn silage in Pennsylvania. J. Prod. Agric. 5:519.

Gehman, A. M., P. J. Kononoff, C. R. Mullins, and B. N. Janicek. 2008. Evaluation of nitrogen utilization and the effects of monensin in dairy cows fed brown midrib corn silage. J. Dairy Sci. $91: 288-300$

Giuberti, G., A. Gallo, F. Masoero, L. F. Ferraretto, P. C. Hoffman, and R. D. Shaver. 2014. Factors affecting starch utilization in large animal food production system: A review. Starke 66:72-90.

Glenn, F. B. 2013. Introducing leafy floury hybrids for improved silage yield and quality. Pages 49-58 in Proc. Cornell Nutr. Conf., East 
Syracuse, NY. Department of Animal Science, Cornell University, Ithaca, NY.

Gorniak, T., L. Huther, U. Meyer, P. Lebzien, G. Breves, K. H. Sudekum, and S. Danicke. 2014a. Digestibility, ruminal fermentation, ingesta kinetics and nitrogen utilization in dairy cows fed diets based on silage of a brown midrib or a standard maize hybrid. Arch. Anim. Nutr. 68:143-158.

Gorniak, T., U. Meyer, F. Hackelsperger, and S. Danicke. 2014b. Effects of a brown-midrib corn hybrid on nutrient digestibility in wethers and on dry matter intake, performance, rumen and blood variables in dairy cows. J. Anim. Physiol. Anim. Nutr. (Berl.) 98:300-309.

Grant, R. J., K. C. Fanning, D. Kleinschmit, E. P. Stanisiewski, and G. F. Hartnell. 2003. Influence of glyphosate-tolerant (event nk603) and corn rootworm protected (event MON863) corn silage and grain on feed consumption and milk production in Holstein cattle. J. Dairy Sci. 86:1707-1715.

Greenfield, T. L., R. L. Baldwin VI, R. A. Erdman, and K. R. McLeod. 2001. Ruminal fermentation and intestinal flow of nutrients by lactating cows consuming brown midrib corn silages. J. Dairy Sci. 84:2469-2477.

Grummer, R. R. 1991. Effect of feed on the composition of milk fat. J. Dairy Sci. 74:3244-3257.

He, M., and L. E. Armentano. 2011. Effect of fatty acid profile in vegetable oils and antioxidant supplementation on dairy cattle performance and milk fat depression. J. Dairy Sci. 94:2481-2491.

He, M., K. L. Perfield, H. B. Green, and L. E. Armentano. 2012. Effect of dietary fat blend enriched in oleic or linoleic acid and monensin supplementation on dairy cattle performance, milk fatty acid profiles, and milk fat depression. J. Dairy Sci. 95:1447-1461.

Holt, M. S., J.-S. Eun, C. R. Thacker, A. J. Young, X. Dai, and K. E. Nestor Jr.. 2013a. Effects of feeding brown midrib corn silage with a high dietary concentration of alfalfa hay on lactational performance of Holstein dairy cows for the first 180 days of lactation. J. Dairy Sci. 96:515-523.

Holt, M. S., K. Neal, J.-S. Eun, A. J. Young, J. O. Hall, and K. E. Nestor Jr.. 2013b. Corn silage hybrit type and quality of alfalfa hay affect dietary nitrogen utilization by early lactating dairy cows. J. Dairy Sci. 96:6564-6576.

Holt, M. S., C. M. Williams, C. M. Dschaak, J.-S. Eun, and A. J. Young. 2010. Effects of corn silage hybrids and dietary nonforage fiber sources on feed intake, digestibility, ruminal fermentation, and productive performance of lactating Holstein dairy cows. J. Dairy Sci. 93:5397-5407.

Hutchison, W. D., E. C. Burkness, P. D. Mitechell, R. D. Moon, T. W. Leslie, S. J. Fleischer, M. Abrahamson, K. L. Hamilton, K. L. Steffey, M. E. Gray, R. L. Hellmich, L. V. Kaster, T. E. Hunt, R. J. Wright, K. Pecinovsky, T. L. Rabaey, B. R. Flood, and E. S. Raun. 2010. Areawide suppression of European Corn Borer with Btmaize reaps savings to non-Bt maize growers. Science 330:222-225.

Ipharraguerre, I. R., R. S. Younker, J. H. Clark, E. P. Stanisiewski, and G. F. Hartnell. 2003. Performance of lactating dairy cows fed corn as whole plant silage and grain produced from a glyphosatetolerant corn (event NK603). J. Dairy Sci. 86:1734-1741.

Ivan, S. K., R. J. Grant, D. Weakley, and J. Beck. 2005. Comparison of a corn silage hybrid with high cell-wall content and digestibility with a hybrid of lower cell-wall content on performance of holstein cows. J. Dairy Sci. 88:244-254.

Johnson, L., J. H. Harrison, C. Hunt, K. Shinners, C. G. Doggett, and D. Sapienza. 1999. Nutritive value of corn silage as affected by maturity and mechanical processing: A contemporary review. J. Dairy Sci. 82:2813-2825.

Johnson, L. M., J. H. Harrison, D. Davidson, J. L. Robutti, M. Swift, W. C. Mahanna, and K. Shinners. 2002a. Corn silage management I: Effects of hybrid, maturity, and mechanical processing on chemical and physical characteristics. J. Dairy Sci. 85:833-853.

Johnson, L. M., J. H. Harrison, D. Davidson, M. Swift, W. C. Mahanna, and K. Shinners. 2002b. Corn silage management II: Effects of hybrid, maturity, and mechanical processing on digestion and energy content. J. Dairy Sci. 85:2913-2927.
Jung, H., and J. Lauer. 2011. Corn silage fiber digestibility: Key points, historical trends, and future opportunities. Pages 30-44 in Proc. 72nd MN Nutr. Conf., Owatonna, MN. Department of Animal Science, University of Minnesota, St-Paul.

Jung, H. G., D. R. Mertens, and R. L. Phipps. 2011. Effect of reduced ferulated-mediated lignin/arabinoxylan cross-linking in corn silage on feed intake, digestibility, and milk production. J. Dairy Sci. 94:5124-5137.

Jung, H. G., D. A. Samac, and G. Sarath. 2012. Modifying crops to increase cell wall digestibility. Plant Sci. 185-186:65-77.

Klopfenstein, T. J., G. E. Erickson, and L. L. Berger. 2013. Maize is a critically important source of food, feed, energy, and forage in the USA. Field Crops Res. 153:5-11.

Kuehn, C. S., J. G. Linn, D. G. Johnson, H. G. Jung, and M. I. Endres. 1999. Effect of feeding silages from corn hybrids selected for leafiness or grain to lactating dairy cattle. J. Dairy Sci. 82:2746-2755.

Kung, L. Jr., B. M. Moulder, C. M. Mulrooney, R. S. Teller, and R. J. Schmidt. 2008. The effect of silage cutting height on the nutritive value of a normal corn silage hybrid compared with brown midrib corn silage fed to lactating cows. J. Dairy Sci. 91:1451-1457.

LaCount, D. W., J. K. Drackley, T. M. Cicela, and J. H. Clark. 1995. High oil corn as silage or grain for dairy cows during an entire lactation. J. Dairy Sci. 78:1745-1754.

Lauer, J. G., J. G. Coors, and P. J. Flannery. 2001. Forage yield and quality of corn cultivars developed in different eras. Crop Sci. 41:1449-1455.

Lauer, J. G., R. D. Shaver, J. G. Coors, P. Hoffman, and N. DeLeon. 2009. Evaluating performance of corn hybrids for silage production on Wisconsin farms. Pages 181-182 in Proc. XVth International Silage Conference, Madison, WI. United States Dairy Forage Research Center, Madison, WI.

Lebaka, N. G., J. G. Coors, R. D. Shaver, S. Bertics, A. GuiterrezRojas, M. Menz, and J. Bertran. 2013. Quantitative trait loci for ruminal degradability in opaque endosperm2 (o2) maize. Crop Sci. $53: 378-384$

Lopes, J. C., R. D. Shaver, P. C. Hoffman, M. S. Akins, S. J. Bertics, H. Gencoglu, and J. G. Coors. 2009. Type of corn endosperm influences nutrient digestibility in lactating dairy cows. J. Dairy Sci. 92:4541-4548

Maczulak, A. E., B. A. Dehority, and D. L. Palmquist. 1981. Effects of long-chain fatty acids on growth of rumen bacteria. Appl. Environ. Microbiol. 42:856-862.

Marita, J. M., W. Vermerris, J. Ralph, and R. D. Hatfield. 2003. Variations in the cell wall composition of maize brown midrib mutants. J. Agric. Food Chem. 51:1313-1321.

Masoero, F., A. Gallo, C. Zanfi, G. Giuberti, and M. Spanghero. 2011. Effect of nitrogen fertilization on chemical composition and rumen fermentation of different parts of plants of three corn hybrids. Anim. Feed Sci. Technol. 164:207-216.

Moreira, V. R., H. S. Santos, L. D. Satter, and I. B. M. Sampaio. 2003 Feeding high forage diets to lactating dairy cows. Arq. Bras. Med. Vet. Zootec. 55:197-202.

Nennich, T. D., J. G. Linn, D. G. Johnson, M. I. Endres, and H. G. Jung. 2003. Comparison of feeding corn silages from leafy or conventional corn hybrids to lactating dairy cows. J. Dairy Sci. 86:2932-2939.

Ngonyamo-Majee, D., R. D. Shaver, J. G. Coors, D. Sapienza, and J. G. Lauer. 2009. Influence of single-gene mutations, harvest maturity and sample processing on ruminal in situ and post-ruminal in vitro dry matter and starch degradability of corn grain by ruminants. Anim. Feed Sci. Technol. 151:240-259.

Nolan, E., and P. Santos. 2012. The contribution of genetic modification to changes in corn yield in the United States. Am. J. Agric. Econ. 94:1171-1188.

NRC. 2001. Nutrient Requirements of Dairy Cattle. 7th rev. ed. Natl. Acad. Sci., Washington, D.C.

Oba, M., and M. S. Allen. 1999a. Effects of brown midrib 3 mutation in corn silage on dry matter intake and productivity of high yielding dairy cows. J. Dairy Sci. 82:135-142.

Oba, M., and M. S. Allen. 1999b. Evaluation of the importance of the digestibility of neutral detergent fiber from forage: Effects on 
dry matter intake and milk yield of dairy cows. J. Dairy Sci. 82:589-596.

Oba, M., and M. S. Allen. 2000a. Effects of brown midrib 3 mutation in corn silage on productivity of dairy cows fed two concentrations of dietary neutral detergent fiber: 1 . Feeding behavior and nutrient utilization. J. Dairy Sci. 83:1333-1341.

Oba, M., and M. S. Allen. 2000b. Effects of brown midrib 3 mutation in corn silage on productivity of dairy cows fed two concentrations of dietary neutral detergent fiber: 3. Digestibility and microbial efficiency. J. Dairy Sci. 83:1350-1358.

Ostrander, B., M. P. Maillot, S. Toillon, Y. Barrière, M. Pollacsek, and J. M. Besle. 1999. Cell wall phenolics and digestibility of normal and brown midrib maizes in different stem sections and across maturity stages. J. Sci. Food Agric. 79:414-415.

Phipps, R. H., A. K. Jones, A. P. Tingey, and S. Abeyasekera. 2005. Effect of corn silage from an herbicide-tolerant genetically modified variety on milk production and absence of transgenic DNA in milk. J. Dairy Sci. 88:2870-2878.

Qiu, X., M. L. Eastridge, and Z. Wang. 2003. Effects of corn silage hybrid and dietary concentration of forage NDF on digestibility and performance by dairy cows. J. Dairy Sci. 86:3667-3674.

Ramirez, H. A. R., K. Nestor, L. O. Tedeschi, T. R. Callaway, S. E. Dowd, S. C. Fernando, and P. J. Kononoff. 2012. The effect of brown midrib corn silage and dried distillers' grains with solubles on milk production, nitrogen utilization and microbial community structure in dairy cows. Can. J. Anim. Sci. 92:365-380.

SAS Institute Inc. 2004. SAS/STAT 9.1 User's Guide. Version 9.1 ed. SAS Inst. Inc., Cary, NC.

Saxton, A. M. 1998. A macro for converting mean separation output to letter groupings in Proc Mixed. Pages 1243-1246 in Proc. 23rd SAS Users Group Intl., SAS Institute, Cary, NC.

Shaver, R., and R. Kaiser. 2011. Top producing dairy herds in Wisconsin feed more forage than you may think. Accessed Sep. 16, 2014 http://www.uwex.edu/ces/dairynutrition/documents/mfaforage focusnov-2011shaver.pdf.

Shi, G., J. P. Chavas, and J. Lauer. 2013. Commercialized transgenic traits, maize productivity and yield risk. Nat. Biotechnol. 31:111114

St-Pierre, N. R. 2001. Invite review: Integrating qualitative findings from multiple studies using mixed model methodology. J. Dairy Sci. 84:741-755.

Taylor, C. C., and M. S. Allen. 2005a. Corn grain endosperm type and brown midrib 3 corn silage: Feeding behavior and milk yield of lactating cows. J. Dairy Sci. 88:1425-1433.
Taylor, C. C., and M. S. Allen. 2005b. Corn grain endosperm type and brown midrib 3 corn silage: Ruminal fermentation and N partitioning in lactating cows. J. Dairy Sci. 88:1434-1442.

Taylor, C. C., and M. S. Allen. 2005c. Corn grain endosperm type and brown midrib 3 corn silage: Site of digestion and ruminal digestion kinetics in lactating cows. J. Dairy Sci. 88:1413-1424.

Thomas, E. D., P. Mandebvu, C. S. Ballard, C. J. Sniffen, M. P. Carter, and J. Beck. 2001. Comparison of corn silage hybrids for yield, nutrient composition, in vitro digestibility, and milk yield by dairy cows. J. Dairy Sci. 84:2217-2226.

Thomas, H. W., and C. M. Smart. 1993. Crops that stay green. Ann. Appl. Biol. 123:193-219.

Thomison, P. R. 2002. Managing pollen drift in seed maize production. Pages 166-171 in Proc. International Seed Seminar: Trade, Production and Technology. Santiago, Chile. Accessed Sep. 14, 2014 http://www.seedconsortium.org/PUC/pdf\%20files/27-Managing $\% 20$ pollen $\% 20$ drift $\% 20$ in $\% 20$ maize $\% 20$ seed $\% 20$ production.pdf.

Tine, M. A., K. R. McLeod, R. A. Erdman, and R. L. Baldwin VI. 2001. Effects of brown midrib corn silage on the energy balance of dairy cattle. J. Dairy Sci. 84:885-895.

Tsai, C. Y., D. M. Huber, and H. L. Warren. 1978. Relationship of the kernel sink for $\mathrm{N}$ to maize productivity. Crop Sci. 18:399-404.

USDA-ERS. 2014. Feed grains database: Yearbook tables. United States Department of Agriculture. Accessed Sep. 30, 2014. http:// www.ers.usda.gov/data-products/feed-grains-database/feedgrains-yearbook-tables.aspx\#.VBmbAvk7uSo

Weiss, W. P., and D. J. Wyatt. 2000. Effect of oil content and kernel processing of corn silage on digestibility and milk production by dairy cows. J. Dairy Sci. 83:351-358.

Weiss, W. P., and D. J. Wyatt. 2002. Effects of feeding diets based on silage from corn hybrids that differed in concentration and in vitro digestibility of neutral detergent fiber to dairy cows. J. Dairy Sci. 85:3462-3469.

Weiss, W. P., and D. J. Wyatt. 2006. Effect of corn silage hybrid and metabolizable protein supply on nitrogen metabolism of lactating dairy cows. J. Dairy Sci. 89:1644-1653.

Xiccato, G., M. Cinetto, A. Carazzolo, and M. E. Cossu. 1994. The effect of silo type and dry matter content on the maize silage fermentation process and ensiling loss. Anim. Feed Sci. Technol. $49: 311-323$ 
APPENDIX

Table A1. Summary of the 38 references used for the grain and stalk characteristics meta-analysis

\begin{tabular}{|c|c|c|c|c|}
\hline Article & No. $^{1}$ & $\mathrm{DIM}^{2}$ & Category $^{3}$ & Location \\
\hline Akay and Jackson, 2001 & 6 & 79 & G & Kentucky, USA \\
\hline Akins and Shaver, 2014 & $4(32)$ & 105 & $\mathrm{G}, \mathrm{S}$ & Wisconsin, USA \\
\hline \multirow[t]{3}{*}{ Bal et al., 2000} & 24 & 75 & $\mathrm{~S}$ & Wisconsin, USA \\
\hline & 26 & 120 & $\mathrm{~S}$ & Wisconsin, USA \\
\hline & 24 & 75 & $\mathrm{~S}$ & Wisconsin, USA \\
\hline Ballard et al., 2001 & 25 & 240 & S & New York, USA \\
\hline Barlow et al., 2012 & 12 & 66 & $\mathrm{G}, \mathrm{S}$ & Georgia, USA \\
\hline Barrière et al., 2004 & 16 & 51 & $\mathrm{~S}$ & Vienne, France \\
\hline Benefield et al., 2006 & 20 & 79 & $\mathrm{G}$ & Illinois, USA \\
\hline Castro et al., 2010 & 10 & 82 & $\mathrm{~S}$ & Georgia, USA \\
\hline Cherney et al., 2004 & 14 & 84 & $\mathrm{~S}$ & New York, USA \\
\hline Clark et al., 2002 & 16 & 97 & $\mathrm{~S}$ & Wisconsin, USA \\
\hline Dhiman et al., 1999 & 27 & 15 & $\mathrm{G}$ & Wisconsin, USA \\
\hline Ebling and Kung, 2004 & 8 & 143 & $\mathrm{~S}$ & Delaware, USA \\
\hline Fernandez et al., 2004 & 12 & 62 & S & Limagne, France \\
\hline Ferraretto et al., 2015 & $6(48)$ & 105 & $\mathrm{~S}$ & Wisconsin, USA \\
\hline Gehman et al., 2008 & 20 & 101 & $\mathrm{~S}$ & Nebraska, USA \\
\hline Gorniak et al., 2014a & 6 & 88 & $\mathrm{~S}$ & Braunschweig, Germany \\
\hline Gorniak et al., 2014b & 32 & 92 & $\mathrm{~S}$ & Braunschweig, Germany \\
\hline Greenfield et al., 2001 & 5 & 221 & $\mathrm{~S}$ & Maryland, USA \\
\hline Holt et al., 2010 & 8 & 34 & $\mathrm{~S}$ & Utah, USA \\
\hline Holt et al., 2013a & 8 & 1 & $\mathrm{~S}$ & Utah, USA \\
\hline Holt et al., 2013b & 8 & 23 & $\mathrm{~S}$ & Utah, USA \\
\hline \multirow[t]{2}{*}{ Ivan et al., 2005} & 40 & 113 & S & Nebraska, USA \\
\hline & 40 & 140 & S & Nebraska, USA \\
\hline Jung et al., 2011 & 14 & 93 & $\mathrm{~S}$ & Wisconsin, USA \\
\hline Kuehn et al., 1999 & 21 & 3 & $\mathrm{~S}$ & Minnesota, USA \\
\hline Kung et al., 2008 & 27 & 81 & $\mathrm{~S}$ & Delaware, USA \\
\hline LaCount et al., 1995 & 11 & 22 & G & Illinois, USA \\
\hline Moreira et al., 2003 & 16 & 138 & $\mathrm{~S}$ & Wisconsin, USA \\
\hline Nennich et al., 2003 & 20 & 22 & $\mathrm{~S}$ & Minnesota, USA \\
\hline Oba and Allen, 1999a & 32 & 89 & $\mathrm{~S}$ & Michigan, USA \\
\hline Oba and Allen 2000a,b & 8 & 70 & S & Michigan, USA \\
\hline Qiu et al., 2003 & 8 & 106 & $\mathrm{~S}$ & Ohio, USA \\
\hline Ramirez et al., 2012 & 36 & 111 & $\mathrm{~S}$ & Nebraska, USA \\
\hline Taylor and Allen, 2005a,b,c & 8 & 72 & $\mathrm{~S}$ & Michigan, USA \\
\hline Thomas et al., 2001 & 19 & 78 & $\mathrm{~S}$ & New York, USA \\
\hline Tine et al., 2001 & 6 & $\mathrm{NA}^{4}$ & S & Maryland, USA \\
\hline Weiss and Wyatt, 2000 & 8 & 162 & G & Ohio, USA \\
\hline Weiss and Wyatt, 2002 & 8 & 174 & $\mathrm{~S}$ & Ohio, USA \\
\hline Weiss and Wyatt, 2006 & 8 & 138 & $\mathrm{~S}$ & Ohio, USA \\
\hline
\end{tabular}

${ }^{1}$ Number of lactating dairy cows used in trial.

${ }^{2}$ Days in milk average at trial initiation.

${ }^{3}$ Trial compared grain (G) or stalk (S) characteristics.

${ }^{4}$ Data not available; animals described as early lactation cows. 
Table A2. Summary of the 10 references used for genetically modified hybrids meta-analysis

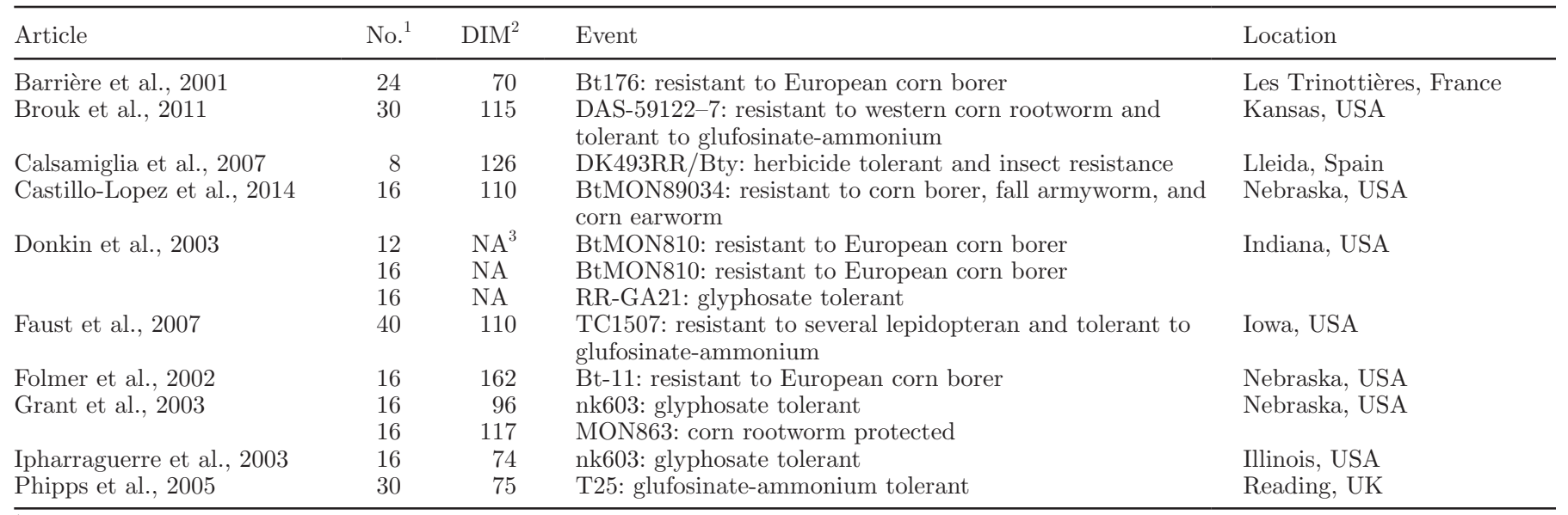

${ }^{1}$ Number of lactating dairy cows used as experimental units.

${ }^{2}$ Days in milk average at trial initiation.

${ }^{3}$ Data not available; animals described as mid-lactation cows. 